\title{
Optimization of a series of heterocycles as survival motor neuron gene transcription enhancers
}

\author{
Sungwoon Choi ${ }^{\mathrm{a}}$, Alyssa N. Calder ${ }^{\mathrm{a}}$, Eliza H. Miller ${ }^{\mathrm{a}}$, Kierstyn P. Anderson ${ }^{\mathrm{a}}$, Dawid K. Fiejtek ${ }^{\mathrm{a}}$ Anne \\ Rietz $^{\mathrm{b}}$, Hongxia Li ${ }^{\mathrm{b}}$, Jonathan J. Cherry ${ }^{\mathrm{b}}$, Kevin M. Quist ${ }^{\mathrm{b}}$, Xuechao Xing ${ }^{\mathrm{a}}$, Marcie A. Glicksman ${ }^{\mathrm{a}}$, Gregory \\ D. Cuny ${ }^{\mathrm{a}}$, Christian L. Lorson ${ }^{\mathrm{c}}$, Elliot A. Androphy ${ }^{\mathrm{b}}$ and Kevin J. Hodgetts ${ }^{\mathrm{a}^{*}}$ \\ ${ }^{a}$ Laboratory for Drug Discovery in Neurodegeneration, Brigham and Women's Hospital and Harvard Medical School, 65 Landsdowne Street, Cambridge, MA, \\ USA. ${ }^{b}$ Department of Dermatology, Indiana University School of Medicine, Indianapolis, IN, USA. ${ }^{c}$ Department of Veterinary Pathobiology, Bond Life Sciences \\ Center, University of Missouri, Columbia, Missouri, USA.

\begin{tabular}{|c|c|}
\hline ARTICLE INFO & ABSTRACT \\
\hline $\begin{array}{l}\text { tory: } \\
2017\end{array}$ & \multirow{2}{*}{$\begin{array}{l}\text { Spinal muscular atrophy (SMA) is a neurodegenerative disorder that results from mutations in the } S M N 1 \text { gene, leading to } \\
\text { survival motor neuron (SMN) protein deficiency. One therapeutic strategy for SMA is to identify compounds that enhance } \\
\text { the expression of the SMN2 gene, which normally only is a minor contributor to functional SMN protein production, but } \\
\text { which is unaffected in SMA. A recent high-throughput screening campaign identified a } 3,4 \text {-dihydro-4-phenyl-2(1H)- } \\
\text { quinolinone derivative (2) that increases the expression of } S M N 2 \text { by } 2 \text {-fold with an EC } 50=8.3 \mu \mathrm{M} \text {. A structure-activity } \\
\text { relationship (SAR) study revealed that the array of tolerated substituents, on either the benzo portion of the quinolinone or } \\
\text { the 4-phenyl, was very narrow. However, the lactam ring of the quinolinone was more amenable to modifications. For } \\
\text { example, the quinazolinone }(\mathbf{9 a}) \text { and the benzoxazepin-2(3H)-one }(\mathbf{1 9}) \text { demonstrated improved potency and efficacy for } \\
\text { increase in } S M N 2 \text { expression as compared to } \mathbf{2} .2017 \text { Elsevier Ltd. All rights reserved. }\end{array}$} \\
\hline & \\
\hline
\end{tabular}

Spinal muscular atrophy (SMA) is a neurodegenerative disease characterized by progressive muscle wasting, loss of motor function and premature death in the most severe cases. ${ }^{1-3}$ Two genes, SMN1 and SMN2, produce survival motor neuron (SMN) protein, ${ }^{4-6}$ which is ubiquitously expressed with the highest levels in the spinal $\operatorname{cord}^{7}$ and functions in the assembly of spliceosomal small nuclear ribonucleoproteins. ${ }^{8}$ The majority of SMN protein normally is produced from the SMN1 gene, while the almost identical SMN2 gene only produces approximately $10 \%$ of functional protein. ${ }^{9,10}$

SMA results from mutations within exon 7 of $S M N 1$, leading to SMN protein deficiency. ${ }^{11}$ The clinical severity of this disease is, therefore, indirectly proportional to the copy number of SMN2 genes, the sole source of protein in these patients. ${ }^{12,13}$ Although the threshold level of SMN protein necessary to maintain healthy motor neurons is not known, it has been estimated that increasing the amount of functional protein by only 2- or 3-fold may be clinically significant. ${ }^{14}$ Thus, the SMN2 gene has become a therapeutic target, in which multiple strategies (i.e., small molecules, antisense oligonucleotide) work to increase the transcription of $S M N 2$, increase the inclusion of exon $7 S M N 2$, stabilize the full-length exon-7 included SMN2 mRNA, or stabilize the SMN protein. ${ }^{15-17}$ As SMA is the leading heritable cause of infant mortality, it is critical to build upon the one recently FDA-approved treatment, Nusinersen, an antisense oligonucleotide $^{18}$ and to provide a variety of treatment options with different modes of action. Several repurposed drugs, such as riluzole, phenylbutyrate, valproic acid, albuterol and hydroxyurea, have advanced into clinical trials, but none has elicited convincing improvement in muscle function or survival in SMA. Currently, there are several small molecules in Phase I to Phase III clinical trials for SMA, including compounds that increased exon 7 inclusion of SMN2. ${ }^{19}$

Previously, we reported an SMN2-lucifrase reporter assay for identifying compounds that increase SMN expression from the SMN2 gene and its use in high-throughput screening. ${ }^{20}$ Using the reporter assay, we discovered two hit compounds, LDN-75654 (1) and LDN-76070 (2) (Figure 1), that increase expression of SMN2 by 2-fold, but that have different mechanisms of action than the small molecules already in clinical trials to treat SMA. Compound 1 increases the stability of SMN protein, whereas compound $\mathbf{2}$ acts in a transcriptional manner. ${ }^{21}$

We recently reported the structure-activity relationship (SAR) of analogs of the 5-isopropylisoxazole-3-carboxamide $\mathbf{1 .}^{22}$ In this paper, we report preliminary SAR of the 3,4-dihydro-4-phenyl2(1H)-quinolinone 2 for increasing SMN expression.

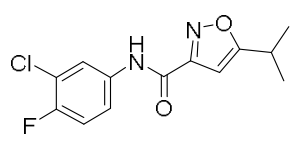

LDN-75654 (1) $\mathrm{EC}_{50}=1.8 \mu \mathrm{M}(242 \%)$

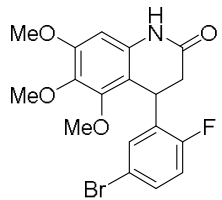

LDN-76070 (2)

$\mathrm{EC}_{50}=8.3 \mu \mathrm{M}(186 \%)$
Figure 1. Two SMN mRNA expression enhancers identified following high-throughput screening.

The 3,4-dihydro-4-phenyl-2(1H)-quinolinone derivatives were prepared according to the procedure outlined in Scheme 1. A three-component coupling of an aniline (3), aromatic aldehyde (4) and Meldrum's acid in refluxing ethanol generated the

This is the author's manuscript of the article published in final edited form as:

Choi, S., Calder, A. N., Miller, E. H., Anderson, K. P., Fiejtek, D. K., Rietz, A., ... Hodgetts, K. J. (2017). Optimization of a series of heterocycles as survival motor neuron gene transcription enhancers. Bioorganic \& Medicinal Chemistry Letters. 
quinolinones 5a-m in good yield. ${ }^{23}$ These compounds were transformed further into the methyl substituted derivatives $\mathbf{6 a - b}$, which were isolated as mixture of cis- and trans-isomers.<smiles>FNc1ccccc1</smiles>

3

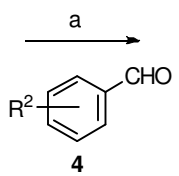

b<smiles>[R][R]1ccccc1C1c2ccccc2N([R])C(=O)C1C</smiles>

$6 a, 6 b$
Scheme 1. (a) Meldrum's acid, $\mathrm{EtOH}, 85^{\circ} \mathrm{C}, 16 \mathrm{~h}$ (55-78\%); (b) $\mathrm{BuLi}, \mathrm{THF}, 0^{\circ} \mathrm{C}$ then $\mathrm{MeI}(48 \%)$.

A series of 3,4-dihydro-quinazolinone derivatives 9a-9l was prepared according to the procedures outlined in Scheme 2. Anilines $\mathbf{3}$ were treated with potassium isocyanate to give the ureas 8 (e.g., $\mathrm{R}=\mathrm{H}$ ). Alternatively, phenyl isocyanates 7 were treated with primary amines to yield substituted ureas $\mathbf{8}(e . g ., \mathrm{R}=$ alkyl). The ureas then were treated with catalytic methane sulfonic acid in refluxing toluene, with azeotropic removal of water, to produce the 3,4-dihydro-quinazolinones 9a-9r.

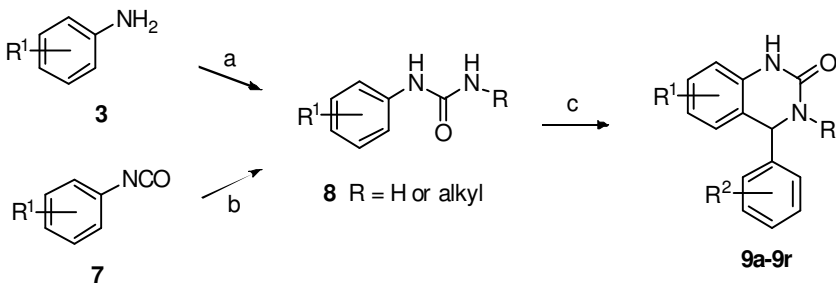

Scheme 2. (a) KNCO, AcOH, RT; (84-97\%); (b) $\mathrm{RNH}_{2}$, THF, $0{ }^{\circ} \mathrm{C}$ to RT (63-89\%); (c) $\mathrm{R}^{2} \mathrm{PhCHO}$, cat. $\mathrm{MeSO}_{3} \mathrm{H}$, toluene, reflux (31$81 \%)$.

The synthesis of the 2-quinazolinone $\mathbf{1 3}$ and the seven-membered 1,4-benzodiazepin-2-one $\mathbf{1 4}$ is outlined in Scheme $\mathbf{3}$. The pivolate-protected 3,4,5-trimethoxylaniline $\mathbf{1 0}$ was lithiated with butyllithium in THF at $-78^{\circ} \mathrm{C}$, and the resulting anion was quenched with methyl 5-chloro-2-fluorobenzoate to give the ketone 11 in modest yield. The pivolate group was cleaved with refluxing sulfuric acid and gave the versatile intermediate 12. For example, the ketone $\mathbf{1 2}$ was treated with trichloroacetyl chloride, and the product, upon treatment with ammonium acetate, cyclized to $\mathbf{1 3}$. On the other hand, the ketone $\mathbf{1 2}$ also was treated with glycine ethyl ester, with azeotropic removal of water, and gave the 1,3-dihydro-5-phenyl-2H-1,4-benzodiazepin-2-one $\mathbf{1 4}$<smiles>COc1cc(NC(=O)C(C)(C)C)cc(OC)c1OCCOc1cc(NC(=O)C(C)(C)C)c(C(=O)c2cc(Cl)ccc2F)c(OC)c1OC</smiles><smiles>COc1cc2[nH]c(=O)nc(-c3cc(Cl)ccc3F)c2c(OC)c1OC</smiles><smiles>COc1cc2c(c(OC)c1OC)C(c1cc(Cl)ccc1F)=NCC(=O)N2</smiles>

14

Scheme 3. (a) BuLi, THF $-78^{\circ} \mathrm{C}$ then methyl 5-chloro-2fluorobenzoate (15\%); (b) $\mathrm{H}_{2} \mathrm{SO}_{4}, \mathrm{EtOH}$, reflux (57\%); (c) $\mathrm{Cl}_{3} \mathrm{CCOCl}, \mathrm{DCM}, \mathrm{Et}_{3} \mathrm{~N}$, RT; (d) $\mathrm{NH}_{4} \mathrm{OAc}, \mathrm{DMSO}, 80^{\circ} \mathrm{C}$ (41\% over 2-steps); (e) $\mathrm{HCl} \bullet \mathrm{NH}_{2} \mathrm{CH}_{2} \mathrm{CO}_{2} \mathrm{Et}$, Py, Dean-Stark trap, reflux, $24 \mathrm{~h}$ $(38 \%)$.

Several oxygen-containing heterocycles (e.g., 16, 19-21) also were prepared from the ketone 12 (Scheme 4 and Scheme 5). Ketone 12 was reduced to the racemic alcohol 15 with sodium borohydride in ethanol. Treatment of $\mathbf{1 5}$ with carbonyl diimidazole (CDI) directly gave the oxazinone $\mathbf{1 6}$ in good yield. Acylation of 15 with 2-bromoacetyl chloride or 2bromopropionyl chloride gave the amides $\mathbf{1 7}$ and $\mathbf{1 8}$, respectively. Treatment of $\mathbf{1 7}$ with two equivalents of sodium hydride gave the 7-membered benzoxazepin-2(3H)-one 19 in moderate yield. ${ }^{25}$ Similarly, cyclization of $\mathbf{1 8}$ gave the 3-methylbenzoxazepin-2(3H)-one $\mathbf{2 0}$ as a mixture of diastereoisomers. Finally, treatment of $\mathbf{1 9}$ with methyl iodide gave the $N$-methyl amide 21.
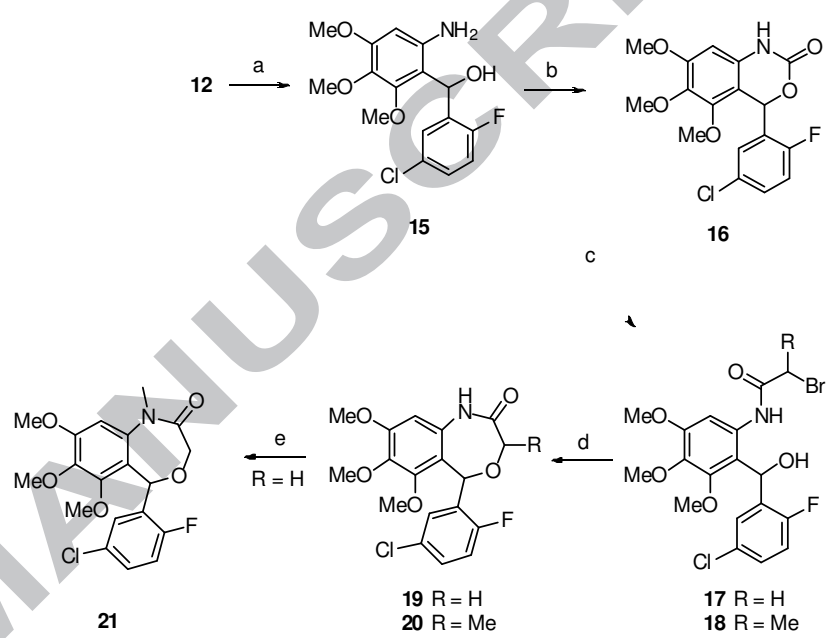

Scheme 4. (a) $\mathrm{NaBH}_{4}$, EtOH, RT (82\%); (b) CDI, THF, RT (76\%); (c) $\mathrm{BrCHRC}(\mathrm{O}) \mathrm{Cl}, \mathrm{Et}_{2} \mathrm{O}, \mathrm{Et}_{3} \mathrm{~N}, 0^{\circ} \mathrm{C}$ to $\mathrm{RT}(62-73 \%)$; (d) $\mathrm{NaH}, \mathrm{THF}$, RT then reflux (43-72\%); (e) MeI, $\mathrm{Cs}_{2} \mathrm{CO}_{3}$, THF, RT (81\%).

The synthesis of the 5-methyl substituted benzoxazepinone $\mathbf{2 3}$ is outlined in Scheme 5. Treatment of the ketone 12 with methyl magnesium bromide gave the racemic tertiary alcohol $\mathbf{2 2}$ in good yield. Reaction of $\mathbf{2 2}$ with 2-bromoacetyl chloride and cyclization gave 23 .

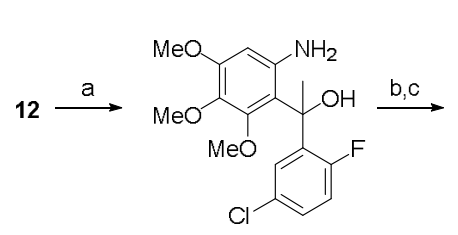

22

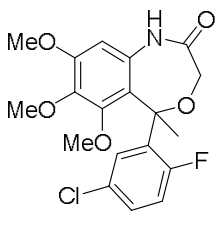

23
Scheme 5. (a) $\mathrm{MeMgBr}$, THF, $0^{\circ} \mathrm{C}(67 \%)$; (b) $\mathrm{BrCH}_{2} \mathrm{C}(\mathrm{O}) \mathrm{Cl}, \mathrm{Et}_{2} \mathrm{O}$, $\mathrm{Et}_{3} \mathrm{~N}, 0^{\circ} \mathrm{C}$ to RT; (c) NaH, THF, RT then reflux (54\% over 2 -steps).

Compounds were assessed for activity in the luciferase reporter assay, as previously described, at various concentrations $(0.1-$ $50 \mu \mathrm{M})$, and were compared to DMSO $(0.1 \%)$ controls. ${ }^{19}$ Doseresponse curves were generated to determine $\mathrm{EC}_{50}$ values and percent maximum increase in SMN2 expression. Unless otherwise stated, all values are the mean \pm S.E.M. of 3 separate experiments. First, the importance of the tri-methoxy group on the aryl ring and methyl substitution at each of the 1- and 3positions of the dihydro-quinolinone was investigated (Figure 2). Removal of either the 7- or 6-methoxy group (e.g., compounds $\mathbf{5 a}$ and $\mathbf{5 b}$ ) resulted in the complete loss of activity. With this information, the methoxy groups were determined to be necessary for activity, and the tri-methoxy group was retained in the remaining analogs described in this optimization study. 
Similarly, the 1- and 3-methyl analogs (e.g., 6a and 6b) were inactive, and these two positions were left unsubstituted in<smiles>COc1ccc2c(c1OC)C(c1cc(Br)ccc1F)CC(=O)N2</smiles>

5a Inactive

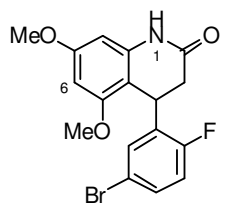

$5 b$ Inactive

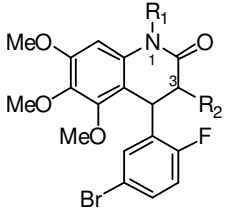

6a $R_{1}=M e, R_{2}=H$ Inactive 6b $R_{1}=H, R_{2}=M e$ Inactive subsequent analogs.

Figure 2. Effects of deletion of individual methoxy substituents and methyl substitution to the dihydro-quinolinone core.

We next investigated the effects on SMN2 expression of substituents on the 4-aryl ring (Table 1). Compounds were prepared following the cyclization procedure outlined in Scheme 1. Removal of either the 5-bromo (e.g., 5c) or the 2-flouro (e.g., 5d) led to a complete loss in activity, indicating the importance of a substituent at both positions. Therefore, we retained the 2flouro substituent and varied the 5-substituent. Replacing the 5bromo by 5 -chloro gave an analog (5e) of similar activity to $\mathbf{2}$, but other electron withdrawing groups were not active (e.g., $\mathbf{5 f}$, $\mathbf{5 g}, \mathbf{5 h}$ and $\mathbf{5 i}$ ). Several other halogenated analogs also were found to be inactive (e.g., $\mathbf{5} \mathbf{j}, \mathbf{5} \mathbf{k}, \mathbf{5} \mathbf{l}$ and $\mathbf{5 m})$.

Table 1. Effects of substitution on the aryl ring of the 3,4dihydro-4-aryl-

2(1H)-quinolinone core.<smiles>COc1cc2c(c(OC)c1OC)C(Br)CC(=O)N2</smiles>

$2,5 a-5 m$

\begin{tabular}{|c|c|c|c|c|c|}
\hline$\#$ & $\mathrm{Ar}$ & $\mathrm{EC}_{50}(\mu \mathrm{M})$ & $\#$ & $\mathrm{Ar}$ & $\mathrm{EC}_{50}(\mu \mathrm{M})$ \\
\hline $\mathbf{2}$ & $2-\mathrm{F}, 5-\mathrm{Br}$ & $8.3(186 \%)$ & $\mathbf{5 c}$ & $2-\mathrm{F}$ & IA \\
\hline $\mathbf{5 d}$ & $3-\mathrm{Br}$ & IA & $\mathbf{5 e}$ & $2-\mathrm{F}, 5-\mathrm{Cl}$ & $12(150 \%)$ \\
\hline $\mathbf{5 f}$ & $2-\mathrm{F}, 5-\mathrm{F}$ & IA & $\mathbf{5 g}$ & $2-\mathrm{F}, 5-\mathrm{CN}$ & IA \\
\hline $\mathbf{5 h}$ & $2-\mathrm{F}, 5-\mathrm{NO}_{2}$ & IA & $\mathbf{5 i}$ & $\begin{array}{c}2-\mathrm{F}, 5- \\
\mathrm{CONH}\end{array}$ & IA \\
\hline $\mathbf{5 j}$ & $2-\mathrm{Cl}, 3-\mathrm{Cl}$ & IA & $\mathbf{5 k}$ & $2-\mathrm{Cl}, 4-\mathrm{Cl}$ & IA \\
\hline $\mathbf{5 l}$ & $3-\mathrm{F}, 4-\mathrm{F}$ & IA & $\mathbf{5 m}$ & $3-\mathrm{Cl}, 4-\mathrm{Cl}$ & IA \\
\hline
\end{tabular}

After the disappointing finding that limited substitution was tolerated on the 4-aryl ring, we chose to explore other cyclic cores. The goal was to identify a more potent core and then to revisit the SAR on the 4-aryl ring. Although the 5-bromo-2fluoro aryl analog 2 was the most active compound, for chemical stability reasons, we chose to retain the 5-chloro-2-fluoro aryl ring at the benzylic position of the new cores (Table 2). The 3,4dihydro-quinazolinone derivative $\mathbf{9 a}$ had very promising activity, although the $N$-methyl (9b) was less active, and both the $N$ propyl (9c) and the 2-quinazolinone (13) were inactive. The seven-membered benzodiazepin-2-one $\mathbf{1 4}$ retained potency similar to the lead 2, although its efficacy was reduced. Several of the oxygen containing heterocycles had interesting activity.

The benzoxazin-2-one $\mathbf{1 6}$ had encouraging activity, and the 7membered benzoxazepin-2(3H)-ones, 19 and 20, had similar activities as 9a. Interestingly, the 3-methyl analog $\mathbf{2 0}$ was tested as a mixture of diastereoisomers, and it is likely that one isomer will retain all activity. $N$-Methylation of the amide (21) was not tolerated, and introduction of a methyl group at the benzylic position (e.g., 23) also was not tolerated.

Table 2. Effects of the heterocyclic core ( $\mathrm{Ar}=2-\mathrm{F}, 5-\mathrm{Cl}-\mathrm{phenyl})$

92

Given the promising activity of the 3,4-dihydro-quinazolinone core (e.g., 9a), we evaluated the SAR for aryl substitution with this heterocyclic core (Table 3). Removal of either the 5-chloro (e.g., 9b) or the 2-flouro (e.g., 9c) led to a partial, but not a complete, loss in activity. Other mono-halogenated analogs retained some activity (e.g., 9d, 9e and 9g), although the methoxy analogs (9h-9j) were inactive. In the next set of analogs, the 2-fluoro substituent was retained, and the 5-substituent was varied. The 5-methyl analog 9k had similar potency, and the 5fluoro 9n was less active. The other 5-substituted analogs (91, 9m and 9o) were inactive but moving the 5-chloro to the 4-position (9p) was tolerated. Although the 2-methoxy analog (9h) activity was restored on incorporation of a 4-chloro (9q) or 5-chloro (9r).

Table 3. Effects of substitution on the aryl ring of the 3,4dihydro-4-arylquinazolin-2(1H)-one core.<smiles>COc1cc2c(c(OC)c1OC)C([Al])NC(=O)N2</smiles>

\begin{tabular}{|c|c|c|c|c|c|}
\hline$\#$ & $\mathrm{Ar}$ & $\mathrm{EC}_{50}(\mu \mathrm{M})$ & $\#$ & $\mathrm{Ar}$ & $\mathrm{EC}_{50}(\mu \mathrm{M})$ \\
\hline $\mathbf{9 a}$ & $2-\mathrm{F}, 5-\mathrm{Cl}$ & $4.1(263 \%)$ & $\mathbf{9 b}$ & $2-\mathrm{F}$ & $10(100 \%)$ \\
\hline $\mathbf{9 c}$ & $3-\mathrm{Cl}$ & $5.2(100 \%)$ & $\mathbf{9 d}$ & $3-\mathrm{F}$ & $25(150 \%)$ \\
\hline $\mathbf{9 e}$ & $4-\mathrm{F}$ & $14.0(150 \%)$ & $\mathbf{9 f}$ & $2-\mathrm{Cl}$ & IA \\
\hline $\mathbf{9 g}$ & $4-\mathrm{Cl}$ & $6.6(150 \%)$ & $\mathbf{9 h}$ & $2-\mathrm{OMe}$ & IA \\
\hline
\end{tabular}




\begin{tabular}{|c|c|c|c|c|c|}
\hline $\mathbf{9 i}$ & $3-\mathrm{OMe}$ & $18(100 \%)$ & $\mathbf{9 j}$ & $4-\mathrm{OMe}$ & IA \\
\hline $\mathbf{9 k}$ & $2-\mathrm{F}, 5-\mathrm{Me}$ & $4.3(125 \%)$ & $\mathbf{9 l}$ & $2-\mathrm{F}, 5-\mathrm{Ph}$ & IA \\
\hline $\mathbf{9 m}$ & $2-\mathrm{F}, 5-\mathrm{CN}$ & IA & $\mathbf{9 n}$ & $2-\mathrm{F}, 5-\mathrm{F}$ & $17(100 \%)$ \\
\hline $\mathbf{9 0}$ & $2-\mathrm{F}, 5-\mathrm{OMe}$ & IA & $\mathbf{9 p}$ & $2-\mathrm{F}, 4-\mathrm{Cl}$ & $6.3(150 \%)$ \\
\hline $\mathbf{9 q}$ & $2-\mathrm{OMe}, 4-\mathrm{Cl}$ & $7.8(200 \%)$ & $\mathbf{9 r}$ & $2-\mathrm{OMe}, 5-\mathrm{Cl}$ & $3.6(225 \%)$ \\
\hline
\end{tabular}

In the preliminary SAR of the quinazolinone series, we did not establish the importance of the 5-methoxy group on SMN enhancing activity (e.g., deletion of the 5-OMe). We did, however, establish the importance of a methoxy group at the analogous position in the benzoxazepin-2(3H)-one series. The synthesis of 26 is outlined in Scheme 6. Palladium-catalyzed addition of the commercially available 5-chloro-2fluorophenylboronic acid and 2-amino-4,5-dimethoxybenzonitril e 24 gave the corresponding ketone, which then was reduced with sodium borohydride in ethanol to give the racemic alcohol 25 . Reaction of $\mathbf{2 5}$ with 2-bromoacetyl chloride, and cyclization as described previously, gave the 7,8-dimethoxy analog 26. Compound 26 was determined to be inactive in the luciferase reporter assay. Combined, the lack of activity for $\mathbf{5 a}, \mathbf{5 b}$, and $\mathbf{2 6}$ establishes the importance of all three methoxy groups for

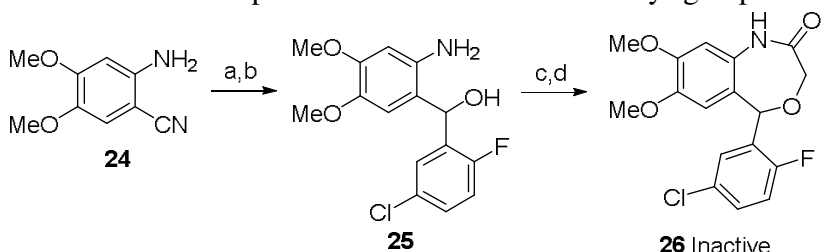

activity.

Scheme 6. (a) 2-F,5-Cl-PhB $(\mathrm{OH})_{2}, \mathrm{Pd}(\mathrm{OAc})_{2}, \mathrm{DMSO}, 24 \mathrm{~h}, 90^{\circ} \mathrm{C}$ (79); (b) $\mathrm{NaBH}_{4}, \mathrm{EtOH}, \mathrm{RT}(77 \%)$; (c) $\mathrm{BrCH}_{2} \mathrm{C}(\mathrm{O}) \mathrm{Cl}, \mathrm{Et}_{2} \mathrm{O}, \mathrm{Et}_{3} \mathrm{~N}$, $0^{\circ} \mathrm{C}$ to RT (67\%); (d) NaH, THF, RT to reflux (71\%).

Two promising analogs, the quinazolinone (9a) and the benzoxazepin-2(3H)-one (19), were evaluated for aqueous solubility and stability in mouse microsomes (Figure 3). Both 9a and 19 had improved aqueous solubility, 9a had promising stability in mouse microsomes although 19 was poor.

Compound 9a was further characterized in secondary assays. We observed a $\sim 2$-fold increase in total SMN protein as well as a 2fold increase in the number of gems in SMA derived fibroblasts following treatment with 9a. Consistent with the earlier discovery that compound $\mathbf{2}$ acts in a transcriptional manner, ${ }^{21}$ compound 9a increased SMN-luciferase protein expression from both the SMN1 and SMN2-luciferase constructs. qRT-PCR analysis revealed that compound $\mathbf{9 a}$ increased the amount of total SMN-luciferase reporter transcripts with a corresponding increase in the amount of exon 7 included transcripts. This effect required 24 hours for full activation and is consistent with the hypothesis that this series is regulating SMN2 expression at the<smiles>COc1cc2c(c(OC)c1OC)C(c1cc(Br)ccc1F)CC(=O)N2</smiles>

LDN-76070 (2) $\mathrm{EC}_{50}=8.3 \mu \mathrm{M}(186 \%)$ Sol @ pH 7.4<1 uM

transcriptional level.

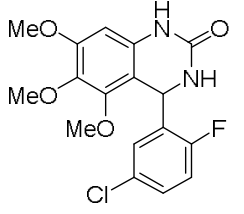

9a

$\mathrm{EC}_{50}=4.1 \mu \mathrm{M}(263 \%)$ Sol @ pH7.4=91 uM $\mathrm{M} \mu \mathrm{s}$ some $\mathrm{T}_{1 / 2}=20 \mathrm{~min}$

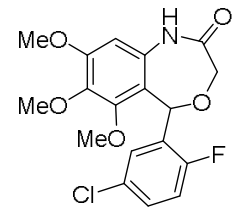

19

$\mathrm{EC}_{50}=5.9 \mu \mathrm{M}(150 \%)$ $\mathrm{M} \mu \mathrm{ssome} \mathrm{T}_{1 / 2}=3 \mathrm{~min}$ Sol @ $\mathrm{pH} 7.4=58 \mathrm{uM}$

Figure 3. Solubility and stability of $\mathbf{9 a}$ and $\mathbf{1 9}$.
Compound 9a was next tested in a preliminary study in $\mathrm{SMN} \Delta 7$ mice. Animals were injected with $20 \mathrm{mg} / \mathrm{kg}$ of compound $9 \mathrm{a}$ in DMSO by intraperotineal injection once daily starting on PND 2. Compound 9a gave a significant increase in lifespan (e.g., 15-day median survival) compared to vehicle treated animals (e.g., 6-day median survival). Compound 9a treated animals also displayed an increase in the ability to right themselves when compared to vehicle treated animals.

Racemic 9a was next separated by supercritical fluid chromatography, using a ChiralPak IC column, into its two individual enantiomers in $>99 \%$ enantiomeric excess. Testing of the individual enantiomers revealed that the fastest eluting enantiomer was inactive, whereas the second enantiomer retained all activity in the SMN2 luciferase reporter assay $\left(\mathrm{EC}_{50}=1.3\right.$ $\mu \mathrm{M}, 185 \%)$.

In summary, we established preliminary SAR of the quinazolinone series and discovered that most changes to the aryl ring substituents led to a loss in activity. We discovered several alternative cores (e.g., quinazolinone the benzoxazepin-2 $(3 \mathrm{H})$ one) that had similar or better activity than 2 and the SAR of the aryl ring was expanded. Compound 9a was identified as a more active analog with improved solubility and stability in mouse microsomes. In an efficacy study in SMN $\Delta 7$ mice, a 2 -fold extension in survival was observed following daily treatment with 9a. The synthesis, determination of absolute stereochemistry and biological evaluation of single enantiomers of 9a and related analogs is in progress and will be reported in due course.

Acknowledgements. The authors thank the NIH (R01 HD064850, R21 NS064349, R21 HD057402), FightSMA, CureSMA, and Gwendolyn Strong Foundation for grant support.

\section{References and Notes}

1. Oskoui, M.; Darras, B. T.; De Vivo, D. C. Spinal muscular atrophy: 125 years later and on the verge of a cure. Academic Press: San Diego, 2017.

2. Pearn, J. Lancet 1980, 1(8174), 919

3. Ahmad, S.; Bhatia, K.; Kannan, A.; Gangwani, L. J. Exp. Neuroscience 2016, 10, 39.

4. Lefebvre, S.; Bürglen, L.; Reboullet, S.; Clermont, O.; Burlet, P.; Viollet, L.; Benichou, B.; Cruaud, C.; Millasseau, P.; Zeviani, M.; Le Paslier, D.; Frézal, J.; Cohen, D.; Weissenbach,; Munnich, A.; Melki, J. Cell 1995, 80, 155.

5. Echaniz-Laguna, A.; Miniou, P.; Bartholdi, D.; Melki, J. Am. J. Hum. Genet. 1999, 64, 1365.

6. Coovert, D. D.; Le, T. T.; McAndrew, P. E.; Strasswimmer, J.; Crawford, T. O.; Mendell, J. R.; Couslon, S. E.; Androphy, E. J.; Prior, T. W.; Burghes, A. H. M. Hum. Mol. Genet. 1997, 6, 1205.

7. Boda, B.; Mas, C.; Giudicelli, C.; Nepote, V.; Guimiot, F.; Levacher, B.; Zvara, A.; Santha, M.; LeGall, I.; Simonneau, M. Eur. J. Hum. Genet. 2004, 12, 729.

8. Gubitz, A. K.; Feng, W.; Dreyfuss, G. Exp. Cell Res. 2004, 296, 51.

9. Lorson, C. L.; Hahnen, E.; Androphy, E. J.; Wirth, B. Proc. Natl. Acad. Sci. U. S. A. 1999, 96, 6307.

10. Monani, U. R.; Lorson, C. L.; Parsons, D. W.; Prior, T. W.; Androphy, E. J.; Burghes, A. H. M.; McPherson, J. D. Hum. Mol. Genet. 1999, 8, 1177.

11. Wirth, B. Hum. Mut. 2000, 15, 228.

12. Gavrilov, D. K.; Shi, X. Y.; Das, K.; Gilliam, T. C.; Wang, C. H. Nat. Genet. 1998, 20, 230.

13. Harada, Y.; Sutomo, R.; Sadewa, A. H.; Akutsu, T.; Takeshima, Y.; Wada, H.; Matsuo, M.; Nishio, H. J. Neurol. 2002, 249, 1211.

14. Meyer, K.; Marquis, J.; Trub, J.; Nlend Nlend, R.; Verp, S.; Reupp, M. D.; Imboden, H.; Barde, I.; Trono, D.; Schumperli, D. Hum. Mol. Genet. 2009, 18, 546.

15. Sunshine, S. S.; Jarecki, J.; MacKenzie, A.; Chen, K. S. Spinal muscular atrophy therapeutics development. Academic Press: San Diego, 2017.

16. Calder, A. N.; Androphy, E. J.; Hodgetts, K. J. Small Molecules in Development for the Treatment of Spinal Muscular Atrophy. $J$ Med Chem 2016, 59, 10067. 
17. Cherry, J. J.; Calder, A. N.; Hodgetts, K. J.; Androphy, E. J. Small molecule approaches to upregulate SMN expression from the SMN2 locus. Academic Press: San Diego, 2017.

18. Ottesen, E. W. Translational Neuroscience 2017, 8, 1.

19. (a) Ratni, H.; Karp, G. M.; Weetall, M.; Naryshkin, N. A.; Paushkin, S. V.; Chen, K. S.; McCarthy, K. D.; Qi, H.; Turpoff, A.; Woll, M. G.; Zhang, X.; Zhang, N.; Yang, T.; Dakka, A.; Vazirani, P.; Zhao, X.; Pinard, E.; Green, L.; David-Pierson, P.; Tuerck, D.; Poirier, A.; Muster, W.; Kirchner, S.; Mueller, L.; Gerlach, I.; Metzger, F. Specific correction of alternative survival motor neuron 2 splicing by small molecules: Discovery of a potential novel medicine to treat spinal muscular atrophy. J. Med. Chem. 2016, 59, 6086-6100. (b) Palacino, J.; Swalley, S. E.; Song, C.; Cheung, A. K.; Shu, L.; Zhang, X.; Van Hoosear, M.; Shin, Y.; Chin, D. N.; Keller, C. G.; Beibel, M.; Renaud, N. A.; Smith, T. M.; Salcius, M.; Shi, X.; Hild, M.; Servais, R.; Jain, M.; Deng, L.; Bullock, C.; McLellan, M.; Schuierer, S.; Murphy, L.; Blommers, M. J.; Blaustein, C.; Berenshteyn, F.; Lacoste, A.; Thomas, J. R.; Roma, G.; Michaud, G. A.; Tseng, B. S.; Porter, J. A.; Myer, V. E.; Tallarico, J. A.; Hamann, L. G.; Curtis, D.; Fishman, M. C.; Dietrich, W. F.; Dales, N. A.; Sivasankaran, R. SMN2 splice modulators enhance U1-pre-mRNA association and rescue SMA mice. Nat. Chem. Biol. 2015, 11, 511-517.

20. (a) Cherry, J. J.; Evans, M. C.; Ni, J.; Cuny, G. D.; Glicksman, M. A.; Androphy, E. J. J. Biomol Screen 2012, 17, 481. (b) Cherry, J. J.; Androphy, E. J. Future Med. Chem. 2012, 4, 1733. (c) Xiao, J.; Marugan, J. J.; Zheng, W.; Titus, S. A.; Southall, N.; Cherry, J. J.; Evans, M.; Androphy, E. J.; Austin, C. P. J. Med. Chem. 2011, 54, 6215.

21. Cherry, J. J.; Osman, E. Y.; Evans, M. C.; Choi, S.; Xing, X.; Cuny, G. D.; Glicksman, M. A.; Lorson, C. L.; Androphy, E. J. EMBO Mol Med 2013, 5, 1035-50.

22. Rietz A., Li H., Quist K.M., Cherry J.J., Lorson C.L., Burnett B.G., Kern N.L., Calder A.N., Fritsche M., Lusic H., Boaler P.J., Choi S., Xing X., Glicksman M.A., Cuny G.D., Androphy E.J., Hodgetts K.J. Discovery of a Small Molecule Probe That PostTranslationally Stabilizes the Survival Motor Neuron Protein for the Treatment of Spinal Muscular Atrophy. J. Med. Chem. 2017, 60, 4594-4610.

23. Wang, X.-S.; Zhang, M.-M.; Zeng, Z.-S.; Shi, D.-Q.; Tu, S.-J.; Wei, X.-Y.; Zong, Z.-M. Tetrahedron Lett. 2005, 46, 7169.

24. Lin, A.J.; Pardini, R.S.; Lillis, B.J.; Sartorelli, A.C. J. Med. Chem. 1974, 17, 668

25. Houlihan, W.J.; Cooke, G.; Denzer, M.; Nicoletti, J. J. Heterocycl. Chem. 1982, 19, 1453. 


\section{Graphical Abstract}

To create your abstract, type over the instructions in the template box below.

\section{Optimization of a series of heterocycles as survival motor neuron gene transcription enhancers}

Sungwoon Choi ${ }^{\mathrm{a}}$, Alyssa N. Calder ${ }^{\mathrm{a}}$, Eliza H. Miller ${ }^{\mathrm{a}}$, Kierstyn P. Anderson ${ }^{\mathrm{a}}$, Dawid K. Fiejtek ${ }^{\mathrm{a}}$, Anne Rietz, Hongxia Li ${ }^{\mathrm{b}}$, Jonathan J. Cherry ${ }^{\mathrm{b}}$, Kevin M. Quist ${ }^{\mathrm{b}}$, Xuechao Xing ${ }^{\mathrm{a}}$, Marcie A. Glicksman ${ }^{\mathrm{a}}$, Gregory D. Cuny ${ }^{\mathrm{a}}$, Christian L. Lorson ${ }^{\mathrm{c}}$, Elliot A. Androphy ${ }^{\mathrm{b}}$ and Kevin J. Hodgetts ${ }^{\mathrm{a}^{*}}$
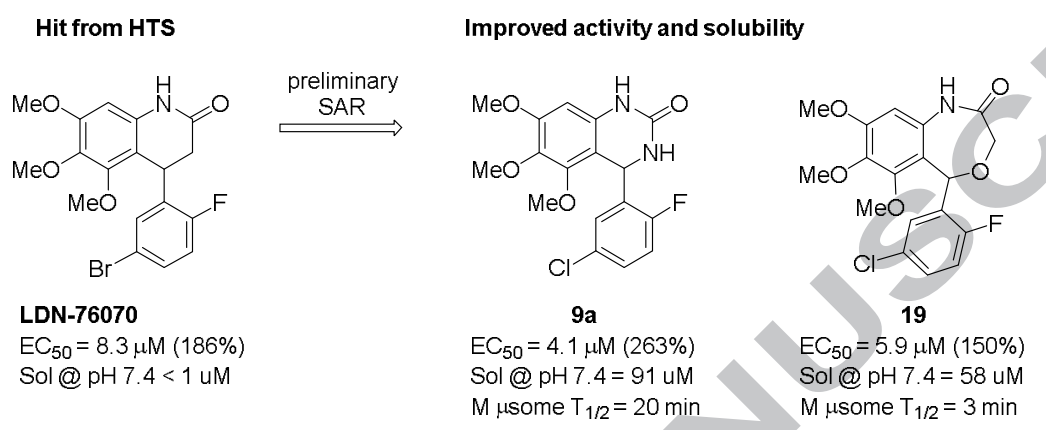

Fonts or abstract dimensions should not be changed or altered. 